Maciej Andrzejewski ${ }^{\text {a) }}$, Paweł Daszkiewicz ${ }^{\text {b) }}$, Jan Strzemkowskic), Andrzej Ziółkowskid)

a) b) c) Lukasiewicz Research Network - Rail Vehicles Institute "TABOR", Poland

d) Poznan University of Technology

\title{
ECOLOGICAL ANALYSIS OF SEMI-TRAILERS TRANSPORTATION
}

\begin{abstract}
The dynamic development of transport recorded in recent decades is an important factor in the economic development of the world on the one hand, and on the other hand, it is a significant source of nuisance and environmental problems. The adverse impact of transport can be felt both in the natural environment and in society, where the dynamic development of this sector has enabled significant civilization development, with the effects varying depending on the level of economic development, the degree of advancement and the use of various transport sectors, geographical location (including climate), and also the sensitivity of the elements of the environment. Considering contemporary transport hazards, it is important to prevent them from occurring, and when that is not possible - limiting their impact on the environment and reducing the scale and extent of negative impacts.

In the paper the environmental and social nuisance of transport of goods loaded in semi-trailers was analyzed. The transport of semi-trailers using intermodal wagons pulled by the diesel locomotive in accordance with the assumptions adopted in the railway with the maximum length of train composition was, inter alia, taken into account. The ecological aspects focused on such harmful compounds as: carbon monoxide, hydrocarbons and nitrogen oxides.
\end{abstract}

Keywords: intermodal transport, semi-trailer, environmental protection, emission of pollutants

JEL: R49, Q530 


\section{Introduction}

The dynamic development of transport recorded in recent decades is an important factor in the economic development of the world on the one hand, and on the other hand, it is a significant source of nuisance and environmental problems. The adverse impact of transport can be felt both in the natural environment and in society, where the dynamic development of this sector has enabled significant civilization development, with the effects varying depending on the level of economic development, the degree of advancement and the use of various transport sectors, geographical location (including climate), and also the sensitivity of the elements of the environment. Considering contemporary transport hazards, it is important to prevent them from occurring, and when that is not possible - limiting their impact on the environment and reducing the scale and extent of negative impacts.

One of the main objectives of the European Transport Policy (ETP) is to increase the share of alternative modes of transport - revitalization of rail transport, promotion of water transport and development of intermodal transport, which will help to reduce the dominance of road transport (Glówny Urząd Statystyczny, 2016). In the European Union, railways account for $6.3 \%$ of total passenger transport and $10.9 \%$ of freight (Rail Transport and Environment, 2015). By 2020 it is planned to increase the share of railways in passenger transport to $10 \%$ and in freight to $15 \%$, which should significantly reduce the negative impact of transport on the environment (Rail Transport and Environment, 2015).

The impact of rail transport on the environment and safety is much lower compared to road transport. The impact of rail transport on the environment mainly relates to the emission of noise and vibration, pollution (from diesel locomotives) and land occupation. The emission of pollutants from rail transport in the European Union is estimated at 1-3\% of total emissions from transport (Ministerstwo Infrastruktury i Rozwoju, 2014). According to the European Environment Agency, rail transport in the EU accounts for $1.5 \%$ of total $\mathrm{NO}_{\mathrm{x}}$ emissions (https://www.eea. europa.eu/pl).

\section{Analysis of emissions per unit of energy}

\subsection{Introduction}

For the purposes of article, an environmental analysis was carried out to compare the environmental impact of the carriage of 38 semi-trailers with a capacity of $24 \mathrm{Mg}$ by road transport and by rail transport. The two transport options were compared, the first was a conventional road transport using long-haul trucks. The second option was to transport the same 38 semi-trailers using combined transport method with the use of the road-rail transport system of standard semi-trailers. For calculations it was assumed that the railcars would be pulled by a diesel locomotive. This is a more impactful environmental version of transport compared to the use of electric locomotives. This choice was made to assess the maximum environmental burden of combined transport in the worst case. It was 
assumed that one train will use 19 wagons to transport semitrailers, where two semi-trailers could be fitted per wagon, which corresponds to the transport of 38 semi-trailers, with the length of the double wagon reaching $31.06 \mathrm{~m}$ and the total length of the train not exceeding $600 \mathrm{~m}$.

\subsection{Research methodology in real traffic conditions}

Evaluation of the road transport option assumes the use of 38 long-haul trucks to transport 38 semi-trailers. To estimate their emissivity, tests in real traffic conditions were conducted. The test vehicle was a heavy vehicle (semi-trailer tractor) equipped with a V8 combustion engine with a displacement of $15.6 \mathrm{dm}^{3}$, power of $412 \mathrm{~kW}$ (560 hp), meeting the Euro V emissions standard (Figure 1). The vehicle had an automated gearbox with a $12+1$ configuration.

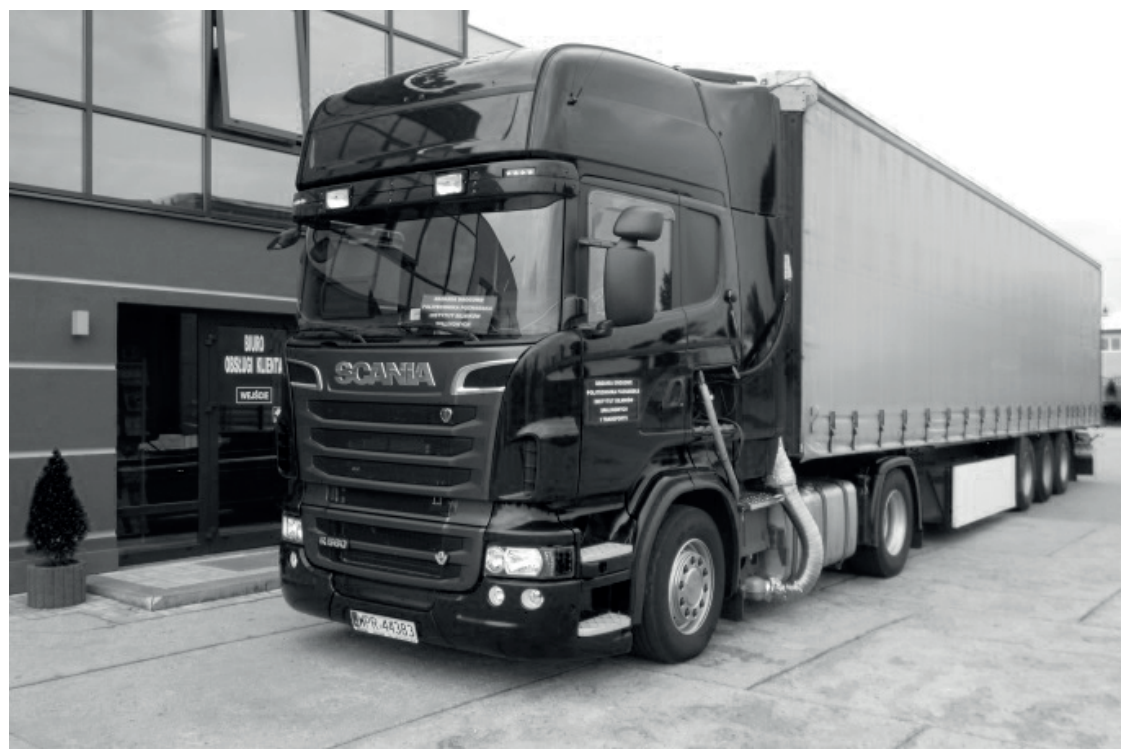

Figure 1. The tested heavy vehicle prepared for exhaust emission measurements Source: (own elaboration)

The route used for the emission testing of a heavy vehicle in real driving conditions began in the industrial district of the city of Koło, where the largest industrial plants are located, and where several dozen heavy vehicles are handled and loaded daily (Figure 2). This district is located by the provincial road No. 270, which is also a transit route for motor vehicles with a permissible total weight above $3,500 \mathrm{~kg}$ through the city. This route ends at the intersection with the national road No. 92 and passes into the provincial road No. 473. Both roads were used as a part of the test route chosen by the authors, which ended at the A2 motorway interchange "Dąbie". The length of the route was $22 \mathrm{~km}$, of which driving in urban conditions was $10 \%$ of the total travel distance. The remaining part of the route was done in extra-urban driving conditions. 


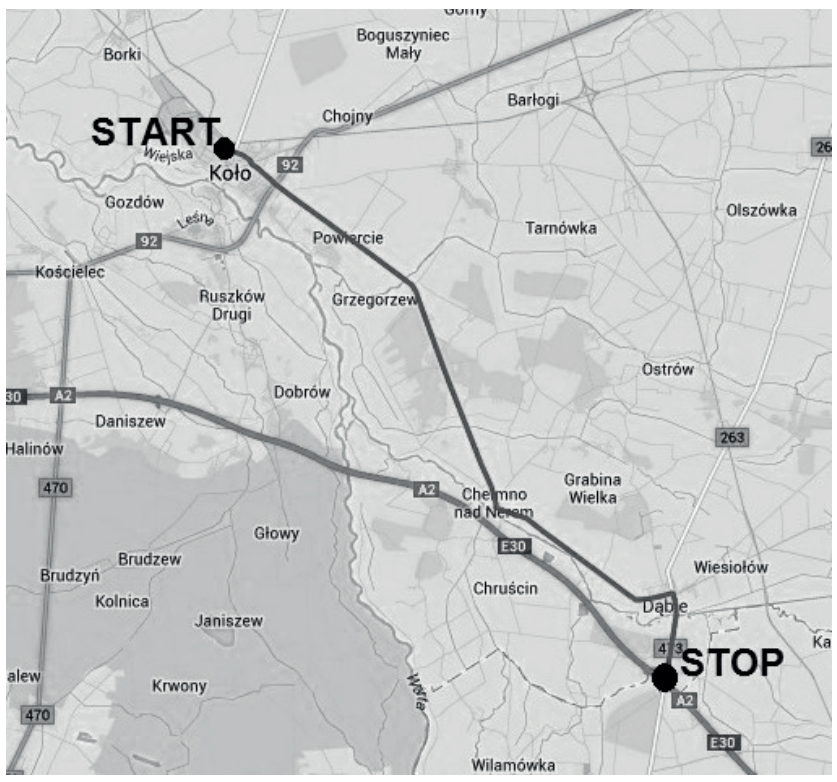

Figure 2. The test route used for exhaust emission measurements of the heavy vehicle Source: (own elaboration)

To measure the exhaust emissions, an advanced measuring tool from the PEMS group for testing in real driving conditions was used - which was the SEMTECH DS instrument from the American manufacturer Sensors Inc. It provides a unique combination of measurement and registration of the following parameters:

- $\mathrm{CO}$ and $\mathrm{CO}_{2}$ concentrations (NDIR - Non-Dispersive Infrared analyzer), $\mathrm{NO}_{x}$ $=\mathrm{NO}+\mathrm{NO}_{2}(\mathrm{NDUV}-\mathrm{Non}$-Dispersive Ultraviolet analyzer), THC (Flame Ionization Detector), $\mathrm{O}_{2}$ (electrochemical sensor);

- mass flow of exhaust gases - a flow meter using a Pitot tube;

- ambient conditions - atmospheric pressure, temperature, humidity;

- position and speed of the vehicle - GPS;

- data from the vehicle diagnostic network.

Analyzing the operating time share characteristics determined in the speed and acceleration intervals of a heavy vehicle, the driving dynamics of the vehicle during measurements was found to be low, which is reflected in the highest share of the $0-0.6 \mathrm{~m} / \mathrm{s}^{2}$ rate of acceleration, representing $94 \%$ of total drive time (Figure $3)$. During the tests, the vehicle travelled at a speed of $0-24 \mathrm{~m} / \mathrm{s}(0-86 \mathrm{~km} / \mathrm{h})$, with the largest recorded share of operating time belonging to speeds in the range of $16-24 \mathrm{~m} / \mathrm{s}(58-86 \mathrm{~km} / \mathrm{h})$. On the entire route the vehicle obtained an average speed of $54 \mathrm{~km} / \mathrm{h}$. Such a speed profile is characteristic for heavy vehicles when navigating the so-called "second category" roads, as these roads often run through small towns and villages where the speed limits are more common. This confirms the obtained significant share of $43 \%$ for the travel speed $0-16 \mathrm{~m} / \mathrm{s}$. When driving on motorways and expressways, heavy vehicles obtain much higher average speeds. 


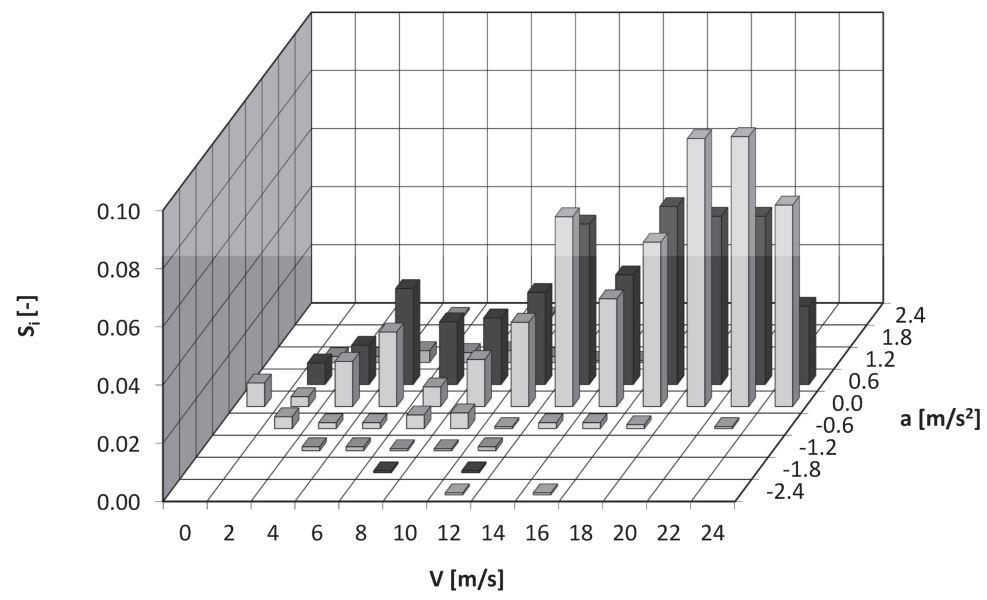

Figure 3. Heavy vehicle drive time share characteristics expressed in speed and acceleration intervals

Source: (own elaboration)

Comparing the real driving conditions of conducting measurements to the characteristics of the heavy-vehicle engine operation confirms the presented thesis that the drive was characterized by a relatively small variation of accelerations. This is mainly due to the engine running in a narrow range of crankshaft rotational speeds - the largest share for engine speed $1200 \mathrm{rpm}$ accounted for $62 \%$ (Figure 4). At this speed, the engine worked mainly in the medium load range of 1200-2000 $\mathrm{Nm}$. This kind of engine operation can be defined as an approximate load characteristic, in the scope of which the engine obtains lower specific fuel consumption than at other operating points.

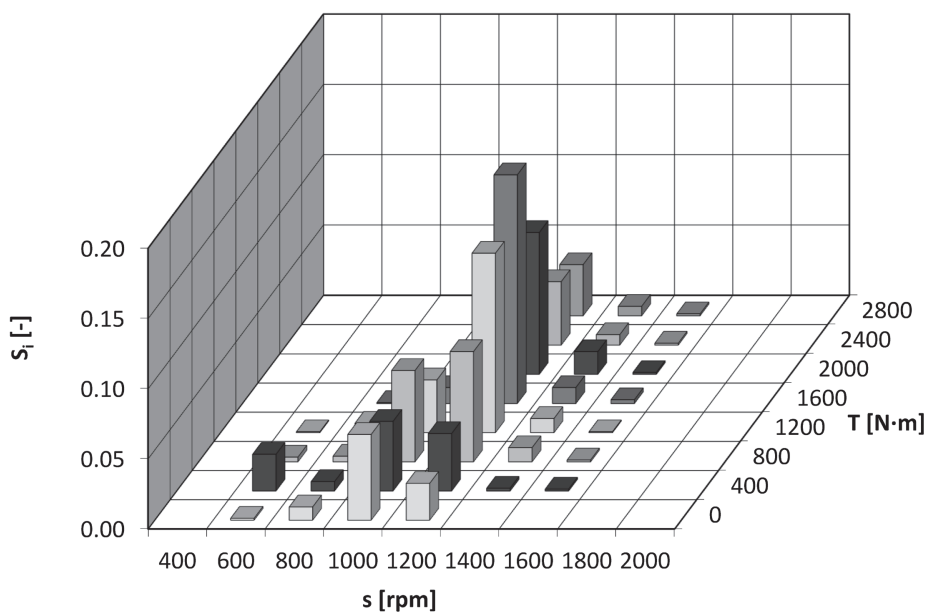

Figure 4. The heavy vehicle engine operating time characteristics in crankshaft speed and load intervals

Source: (own elaboration) 
Based on the measured emission intensity, vehicle speed and registered parameters of the combustion engine operation of the tested vehicle, specific emission values of three basic exhaust compounds were determined. This emission was:

- $\mathrm{CO}-0.77 \mathrm{~g} / \mathrm{kWh}$;

- $\mathrm{HC}-0.38 \mathrm{~g} / \mathrm{kWh}$;

- $\mathrm{NO}_{\mathrm{x}}-1.11 \mathrm{~g} / \mathrm{kWh}$.

For comparison, the Table 1 shows emission values for the analyzed toxic exhaust gases, which were adopted in accordance with current standards (Delphi Automotive Ltd, 2016).

Table 1. Specific emissions of toxic gaseous compounds for the latest emission standards of HDV vehicles

\begin{tabular}{|l|c|c|}
\hline \multicolumn{1}{|c|}{ Exhaust emission } & Euro V & Euro VI \\
\hline $\mathrm{CO}(\mathrm{g} / \mathrm{kWh})$ & 1.5 & 1.5 \\
\hline $\mathrm{HC}(\mathrm{g} / \mathrm{kWh})$ & 0.46 & 0.13 \\
\hline $\mathrm{NO}_{\mathrm{x}}(\mathrm{g} / \mathrm{kWh})$ & 2.0 & 0.4 \\
\hline
\end{tabular}

Source: (Delphi Automotive Ltd, 2016)

\subsection{Results for analyzes}

To compare the environmental impact of the considered transport options, it was necessary to determine the emission values of toxic compounds emitted during the railway transport of semi-trailers using diesel locomotives. The authors' experience in this field and market analysis allowed to indicate the most likely method of train transport of 19 intermodal wagons loaded with 38 semi-trailers with diesel locomotives whose combustion engines presented the values shown in Table 2. For comparative purposes, two diesel locomotives meeting the older exhaust emission standards were compared: ORE B13, UIC 2003 and two modern locomotives, which propulsion units met the Stage III and IV standard. The emission values per unit of energy were based on the data contained in the publication (Pielecha, Pielecha, 2005).

Table 2. Exhaust gas emission values of individual gaseous toxic compound norms for locomotives

\begin{tabular}{|l|c|c|c|c|}
\hline \multirow{2}{*}{ Toxic substance } & \multicolumn{4}{|c|}{ Permissible exhaust emission $(\mathrm{g} / \mathrm{kWh})$} \\
\cline { 2 - 5 } & ORE B13 & UIC 2003 & Stage III & Stage IV \\
\hline $\mathrm{CO}$ & 12.0 & 3.0 & 2.0 & 2.0 \\
\hline $\mathrm{HC}$ & 4.0 & 0.8 & 0.5 & 0.5 \\
\hline $\mathrm{NO}_{x}$ & 24.0 & 9.5 & 6.0 & 1.0 \\
\hline
\end{tabular}

Source: (Pielecha, Pielecha, 2005)

In Figures 5-7 the comparison of total emission values of toxic compounds for the considered transport option of 38 semi-trailers by using trucks was shown. By extending the analysis to include the possibility of transporting the same goods 
by means of intermodal transport with the use of 19 rail cars adapted to loading two semi-trailers each, it was shown that rail transport using even the oldest diesel locomotive, whose combustion engine meets the emission standard ORE B13, is more environmentally friendly and emissions of toxic compounds are lower than for the same transport using 38 modern long-haul trucks.

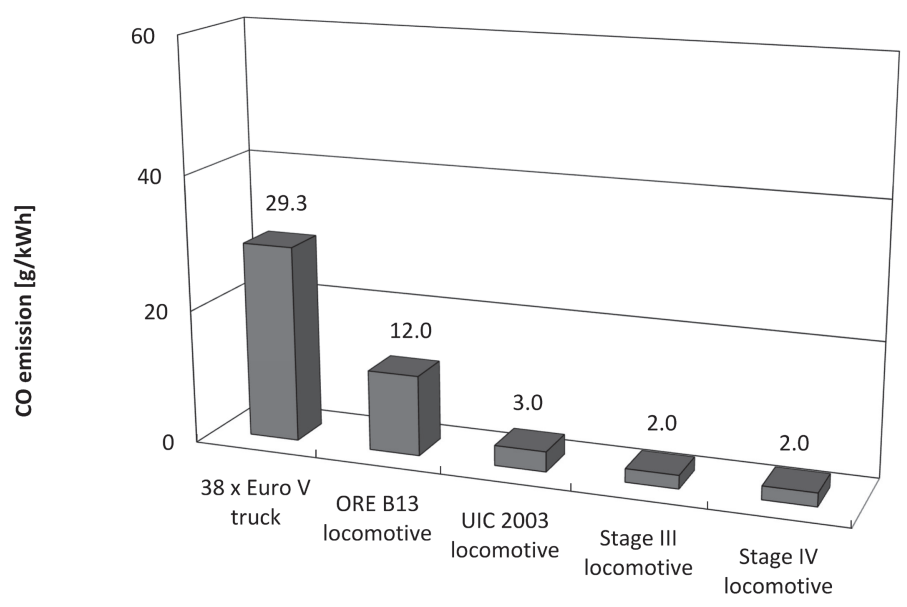

Figure 5. Comparison of $\mathrm{CO}$ emission values of adopted road transport variant with emission standards for diesel locomotives Source: (own elaboration)

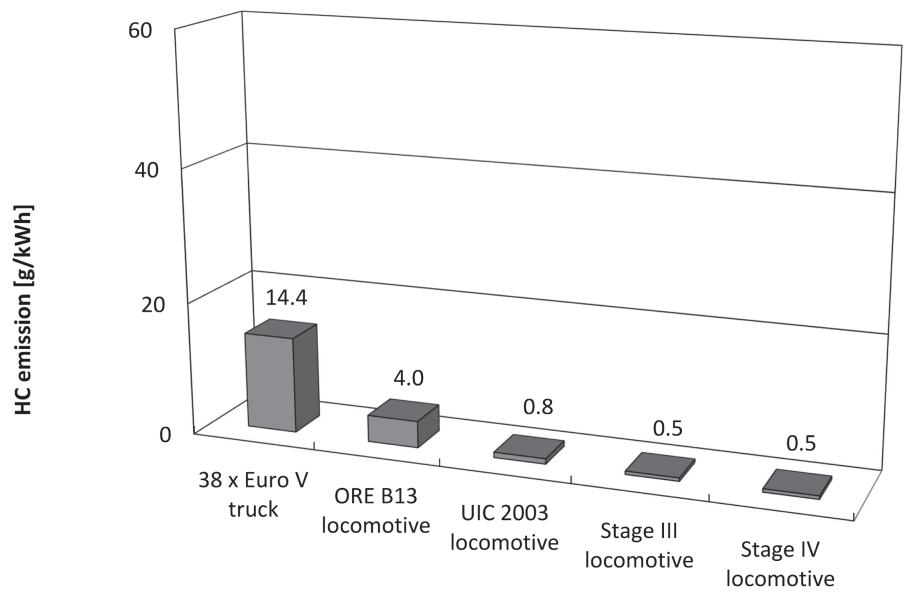

Figure 6. Comparison of HC emission values of adopted road transport variant with emission standards for diesel locomotives Source: (own elaboration) 


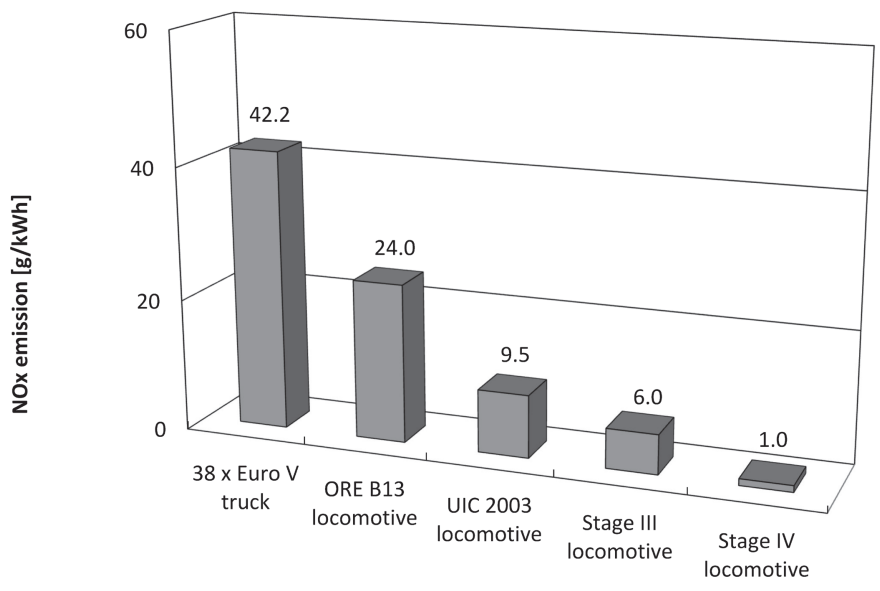

Figure 7. Comparison of $\mathrm{NO}_{\mathrm{x}}$ emission values of adopted road transport variant with emission standards for diesel locomotives

Source: (own elaboration)

\section{Summary}

As shown in Figures 8-10, the difference in emission for $\mathrm{CO}, \mathrm{HC}$ and $\mathrm{NO}_{\mathrm{x}}$ clearly proved that the use of rail transport has a less significant impact on the environment. The discrepancies vary from about $200 \%$ for the oldest diesel locomotive engines of the ORE B13 norm, up to over $4000 \%$ for state-of-the-art diesel locomotives equipped with a Stage IV emission compliant diesel engine.

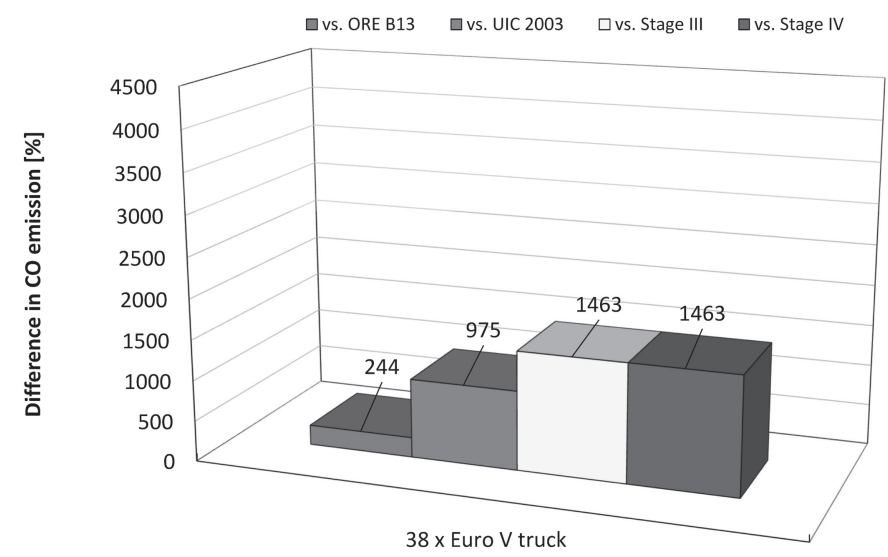

Figure 8. Difference in $\mathrm{CO}$ emissions for adopted road transport variant versus combined transport

Source: (own elaboration) 


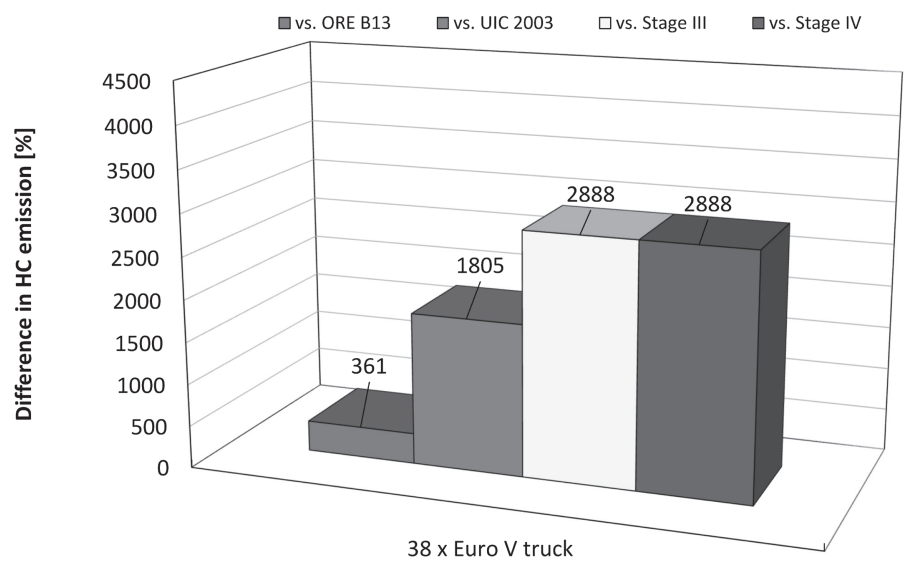

Figure 9. Difference in HC emissions for adopted road transport variant versus combined transport

Source: (own elaboration)

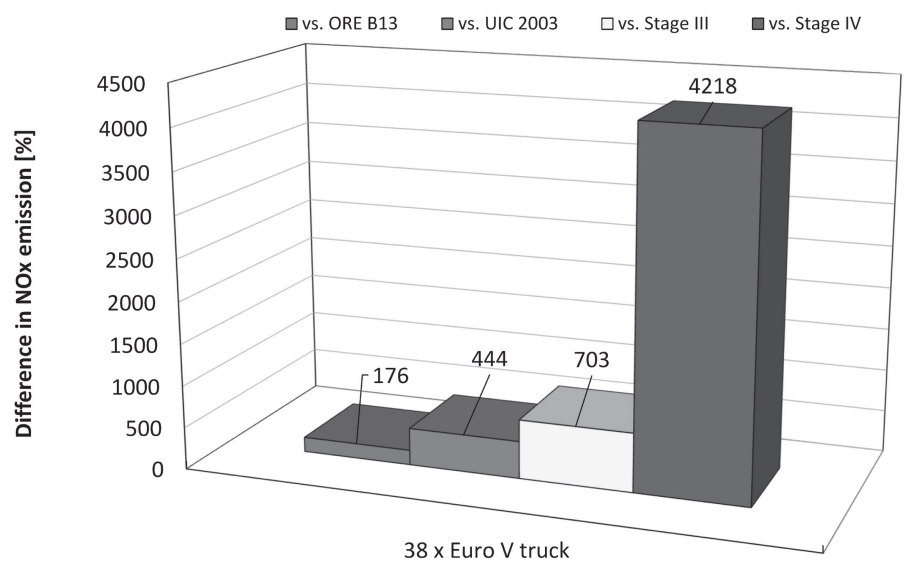

Figure 10. Difference in $\mathrm{NO}_{\mathrm{x}}$ emissions for adopted road transport variant versus combined transport

Source: (own elaboration)

Development of multimodal transport improves the prospects for global markets. In the case of Poland, it is possible to strengthen the country as a liaison between Western Europe and Eastern Europe and Russia. For customers on long-haul routes, multimodal transport gives economic advantages and enables savings. The most important economic benefits of combined transport are generated at a macroeconomic level in a broad socio-economic context. As for the benefits in terms 
of ecological aspects, they occur when modern diesel locomotives are used for transport. The use of old rolling stock causes high levels of pollutant emissions in the exhaust gases, however it is "competitive" with regard to the transportation of numerous long-haul trucks.

\section{References}

Delphi Automotive Ltd (2016), Worldwide Emissions Standards 2016/2017 Heavy Duty and Off-Highway vehicles, Gillingham, United Kingdom.

Europejska Agencja Środowiska (EEA), website https://www.eea.europa.eu/pl [Accessed 20 September 2018].

Główny Urząd Statystyczny (2016), Transport. Wyniki działalności w 2015 r., Warszawa.

Ministerstwo Infrastruktury i Rozwoju (2014), Dokument implementacyjny do strategii rozwoju transportu do 2020 r. (z perspektywa do 2030 r.), Warszawa.

Pielecha, I., Pielecha, J. (2005), Tendencje w przepisach dotyczących emisji związków toksycznych przez silniki pojazdów szynowych, Pojazdy Szynowe, 1, pp. 52-59.

Rail Transport and Environment (2015), Fact \& Figures. The Voice of European Railways, UIC International Union Of Railways, Paris.

\section{Corresponding author}

Maciej Andrzejewski can be contacted at: m.andrzejewski@tabor.com.pl 